\title{
CHEMICAL MODIFICATION OF ERYTHROMYCINS
}

\section{SYNTHESIS AND BIOLOGICAL PROPERTIES \\ OF 6-O-METHYLERYTHROMYCIN B}

\author{
Shigeo Morimoto, Takashi Adachi, Yoko Misawa, Takatoshi Nagate, \\ Yoshiaki Watanabe and SADAFUmi OMUra \\ Research Center, Taisho Pharmaceutical Co., Ltd., \\ 1-403 Yoshino-cho, Ohmiya-shi, Saitama 330, Japan \\ (Received for publication October 7, 1989)
}

\begin{abstract}
6-O-Methylerythromycin $\mathrm{B}$ has been synthesized from erythromycin B via regioselective methylation of the 6-hydroxyl group in $71 \%$ overall yield. This compound shows in vitro antibacterial activity comparable to erythromycins $\mathrm{A}$ and $\mathrm{B}$ and exhibits superior in vivo activity with improved pharmacokinetic properties.
\end{abstract}

In the previous paper we have described the synthesis and the antibacterial activity of $O$-alkyl derivatives of erythromycin A (1, EM-A) ${ }^{1,2)}$. Among them, 6-O-methylerythromycin A (2, clarithromycin, TE-031) showed more potent antibacterial activity than 1 and superior pharmacokinetic properties. Erythromycin B (3, EM-B, 12-deoxyerythromycin A), a biosynthetic precursor of 1 , is produced as a minor product by Streptomyces erythraeus ${ }^{3)}$. We were interested in the synthesis and the biological properties of 6-O-methylerythromycin B (4). Methylation of $2^{\prime}$ - $O, 3^{\prime}$ - $N$-bis(benzyloxycarbonyl)- $N$-demethylerythromycin $\mathrm{B}(\mathbf{8})$, derived from 3 , afforded the 6-O-methylated compound (9) predominantly, whereas methylation of the corresponding EM-A derivative (13) afforded the 11- $O$-methylated compound as the major and the 6-O-methylated compound as the minor product.

This paper describes the synthesis and the biological properties of 6-O-methylerythromycin $\mathrm{B}$ and its related compounds.

\section{Chemistry}

Reaction of EM-B (3) with benzyl chloroformate and $\mathrm{NaHCO}_{3}$ afforded $2^{\prime}-O, 3^{\prime}-\mathrm{N}$-bis(benzyloxycarbonyl)- $N$-demethylerythromycin B (8) in $88 \%$ yield ${ }^{4)}$. Methylation of $\mathbf{8}$ with methyl iodide (MeI, 2.5 equiv)/ $\mathrm{KOH}$ powder (1.5 equiv) in dimethyl sulfoxide (DMSO) - 1,2-dimethoxyethane $(1: 1)$ afforded $9(87 \%)$, the 11-O-methylated compound (10, $6 \%$ ) and the 6,4"-di- $O$-methylated compound (11, $4 \%)$. Methylation of 8 with $\mathrm{MeI}(10 \mathrm{eq}) / \mathrm{NaH}$

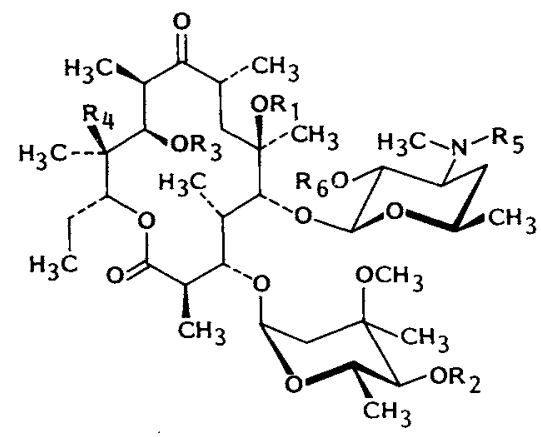

\begin{tabular}{ccccccc}
\hline Compound & $\mathrm{R}_{1}$ & $\mathrm{R}_{2}$ & $\mathrm{R}_{3}$ & $\mathrm{R}_{4}$ & $\mathrm{R}_{5}$ & $\mathrm{R}_{6}$ \\
\hline $\mathbf{1}$ & $\mathrm{H}$ & $\mathrm{H}$ & $\mathrm{H}$ & $\mathrm{OH}$ & $\mathrm{CH}_{3}$ & $\mathrm{H}$ \\
$\mathbf{2}$ & $\mathrm{CH}_{3}$ & $\mathrm{H}$ & $\mathrm{H}$ & $\mathrm{OH}$ & $\mathrm{CH}_{3}$ & $\mathrm{H}$ \\
$\mathbf{3}$ & $\mathrm{H}$ & $\mathrm{H}$ & $\mathrm{H}$ & $\mathrm{H}$ & $\mathrm{CH}_{3}$ & $\mathrm{H}$ \\
$\mathbf{4}$ & $\mathrm{CH}_{3}$ & $\mathrm{H}$ & $\mathrm{H}$ & $\mathrm{H}$ & $\mathrm{CH}_{3}$ & $\mathrm{H}$ \\
$\mathbf{5}$ & $\mathrm{H}$ & $\mathrm{H}$ & $\mathrm{CH}_{3}$ & $\mathrm{H}$ & $\mathrm{CH}_{3}$ & $\mathrm{H}$ \\
$\mathbf{6}$ & $\mathrm{CH}_{3}$ & $\mathrm{CH}_{3}$ & $\mathrm{H}$ & $\mathrm{H}$ & $\mathrm{CH}_{3}$ & $\mathrm{H}$ \\
$\mathbf{7}$ & $\mathrm{CH}_{3}$ & $\mathrm{CH}_{3}$ & $\mathrm{CH}_{3}$ & $\mathrm{H}$ & $\mathrm{CH}_{3}$ & $\mathrm{H}$ \\
$\mathbf{8}$ & $\mathrm{H}$ & $\mathrm{H}$ & $\mathrm{H}$ & $\mathrm{H}$ & $\mathrm{Z}$ & $\mathrm{Z}$ \\
$\mathbf{9}$ & $\mathrm{CH}_{3}$ & $\mathrm{H}$ & $\mathrm{H}$ & $\mathrm{H}$ & $\mathrm{Z}$ & $\mathrm{Z}$ \\
$\mathbf{1 0}$ & $\mathrm{H}$ & $\mathrm{H}$ & $\mathrm{CH}_{3}$ & $\mathrm{H}$ & $\mathrm{Z}$ & $\mathrm{Z}$ \\
$\mathbf{1 1}$ & $\mathrm{CH}_{3}$ & $\mathrm{CH}_{3}$ & $\mathrm{H}$ & $\mathrm{H}$ & $\mathrm{Z}$ & $\mathrm{Z}$ \\
$\mathbf{1 2}$ & $\mathrm{CH}_{3}$ & $\mathrm{CH}_{3}$ & $\mathrm{CH}$ & $\mathrm{H}$ & $\mathrm{Z}$ & $\mathrm{Z}$ \\
$\mathbf{1 3}$ & $\mathrm{H}$ & $\mathrm{H}$ & $\mathrm{H}$ & $\mathrm{OH}$ & $\mathrm{Z}$ & $\mathrm{Z}$ \\
\hline
\end{tabular}

$\mathrm{Z}=\mathrm{COOCH}_{2} \mathrm{C}_{6} \mathrm{H}_{5}$. 
Table 1. ${ }^{1} \mathrm{H}$ and ${ }^{13} \mathrm{C}$ NMR chemical shifts $(\delta)^{\mathrm{a}}$ of 3 and 4.

\begin{tabular}{|c|c|c|c|c|c|c|c|c|c|}
\hline \multirow{2}{*}{ Position } & \multicolumn{2}{|l|}{3} & \multicolumn{2}{|l|}{4} & \multirow{2}{*}{ Position } & \multicolumn{2}{|l|}{3} & \multicolumn{2}{|l|}{4} \\
\hline & ${ }^{1} \mathrm{H}$ & ${ }^{13} \mathrm{C}$ & ${ }^{1} \mathbf{H}$ & ${ }^{13} \mathrm{C}$ & & , ${ }^{1} \mathrm{H}$ & ${ }^{13} \mathrm{C}$ & ${ }^{1} \mathrm{H}$ & ${ }^{13} \mathrm{C}$ \\
\hline 1 & & 176.1 & & 176.1 & $20\left(10-\mathrm{CH}_{3}\right)$ & 0.99 & 9.2 & 0.97 & 9.9 \\
\hline 2 & 2.90 & 44.8 & 2.94 & 44.9 & $21\left(12-\mathrm{CH}_{3}\right)$ & 0.86 & 9.1 & 0.84 & 9.1 \\
\hline 3 & 4.04 & 80.2 & 3.78 & 78.9 & $6-\mathrm{OCH}_{3}$ & & & 3.10 & 50.9 \\
\hline 4 & 2.10 & 39.3 & 2.04 & 38.7 & $1^{\prime}$ & 4.42 & 102.7 & 4.46 & 102.7 \\
\hline 5 & 3.57 & 83.5 & 3.71 & 80.6 & $2^{\prime}$ & 3.22 & 71.1 & 3.19 & 71.1 \\
\hline 6 & & 75.1 & & 78.7 & $3^{\prime}$ & 2.46 & 65.6 & 2.41 & 65.6 \\
\hline 7 & $1.64 / 1.99$ & 38.0 & nd/1.90 & 38.7 & $4^{\prime}$ & $1.13 / 1.65$ & 28.6 & $\mathrm{nd} / \mathrm{nd}$ & 28.6 \\
\hline 8 & 2.74 & 44.8 & 2.60 & 45.5 & $5^{\prime}$ & 3.50 & 68.7 & 3.48 & 68.7 \\
\hline 9 & & 219.6 & & 219.7 & $6^{\prime}\left(5^{\prime}-\mathrm{CH}_{3}\right)$ & 1.22 & 21.5 & 1.23 & 21.5 \\
\hline 10 & 2.98 & 38.9 & 2.92 & 37.8 & $3^{\prime}-\mathrm{N}\left(\mathrm{CH}_{3}\right)_{2}$ & 2.29 & 40.3 & 2.28 & 40.3 \\
\hline 11 & 3.82 & 69.3 & 3.73 & 69.5 & $1^{\prime \prime}$ & 4.90 & 96.2 & 4.94 & 96.2 \\
\hline 12 & 1.65 & 39.8 & nd & 40.3 & $2^{\prime \prime}$ & $1.58 / 2.38$ & 35.0 & $1.60 / 2.37$ & 35.0 \\
\hline 13 & 5.35 & 74.9 & 5.39 & 74.8 & $3^{\prime \prime}$ & & 72.7 & & 72.7 \\
\hline 14 & $1.47 / 1.67$ & 25.5 & $1.46 / 1.72$ & 25.7 & $4^{\prime \prime}$ & 3.01 & 78.0 & 3.03 & 78.0 \\
\hline $15\left(14-\mathrm{CH}_{3}\right)$ & 0.88 & 10.3 & 0.88 & 10.5 & $5^{\prime \prime}$ & 4.04 & 65.8 & 4.02 & 65.8 \\
\hline $16\left(2-\mathrm{CH}_{3}\right)$ & 1.19 & 15.5 & 1.20 & 16.0 & $6^{\prime \prime}\left(5^{\prime \prime}-\mathrm{CH}_{3}\right)$ & 1.29 & 18.4 & 1.31 & 18.4 \\
\hline $17\left(4-\mathrm{CH}_{3}\right)$ & 1.14 & 9.1 & 1.12 & 9.1 & $7^{\prime \prime}\left(3^{\prime \prime}-\mathrm{CH}_{3}\right)$ & 1.24 & 21.5 & 1.26 & 21.5 \\
\hline $18\left(6-\mathrm{CH}_{3}\right)$ & 1.47 & 27.2 & 1.41 & 20.0 & $3^{\prime \prime}-\mathrm{OCH}_{3}$ & 3.22 & 49.5 & 3.33 & 49.5 \\
\hline $19\left(8-\mathrm{CH}_{3}\right)$ & 1.14 & 18.4 & 1.10 & 18.8 & & & & & \\
\hline
\end{tabular}

dispersion (2 eq) in $N, N$-dimethylformamide (DMF) afforded $9(21 \%), 11(51 \%)$ and the $6,11,4^{\prime \prime}$-tri- $O$-methylated compound $(\mathbf{1 2}, 10 \%)$. When large amounts of $\mathrm{NaH}$ dispersion were used in DMF, 12 was obtained in $93 \%$ yield.

Catalytic hydrogenation of 9, 10, 11 and 12 using Pd-Black in EtOH containing $2.5 \mathrm{M}$ acetate buffer (pH 5.0) and reductive $\mathrm{N}$-methylation with formaldehyde afforded 4 (93\%), 11-O-methylerythromycin B $(5,61 \%), 6,4^{\prime \prime}$-di- $O$-methylerythromycin B $(6,69 \%)$ and $6,11,4^{\prime \prime}$-tri- $O$-methylerythromycin B $(7,48 \%)$, respectively.

The molecular formula of 4 was determined as $\mathrm{C}_{38} \mathrm{H}_{69} \mathrm{NO}_{12}$ from elemental analysis, FAB-MS and ${ }^{13} \mathrm{C}$ NMR spectra, indicating the introduction of a methyl group to 3 . The ${ }^{1} \mathrm{H}$ and ${ }^{13} \mathrm{C}$ NMR spectra of 4 were directly compared with those of 3 (Table 1). The ${ }^{1} \mathrm{H}$ NMR spectrum of 4 is similar to that of 3 except for the new $O$-methyl signal at $3.10 \mathrm{ppm}$. In the ${ }^{13} \mathrm{C}$ NMR spectrum, C-6 (78.7 ppm) of 4 is $3.6 \mathrm{ppm}$ further downfield than that of 3. Upfield shifts of C-5 $(-2.9 \mathrm{ppm})$ and C-18 $(-7.2 \mathrm{ppm})$ were also observed. The spectral data of 4 are consistent with the published substituent effect in $2^{2}$. The structure of 4 is therefore determined to be 6-O-methylerythromycin $\mathrm{B}$.

The molecular formulae of 6 and 7 were determined as $\mathrm{C}_{39} \mathrm{H}_{71} \mathrm{NO}_{12}$ and $\mathrm{C}_{40} \mathrm{H}_{73} \mathrm{NO}_{12}$, respectively, from FAB-MS, ${ }^{13} \mathrm{C}$ NMR spectra and elemental analyses, indicating the introduction of two and three methyl groups to 3, respectively. Compound 6 exhibits the new $O$-methyl signal at $3.54 \mathrm{ppm}$ in addition to the 6-O-methyl signal at $3.10 \mathrm{ppm}$. The ${ }^{1} \mathrm{H}$ NMR spectrum of 7 showed one more $O$-methyl signal at $3.44 \mathrm{ppm}$ besides two $O$-methyl signals at 3.54 and $3.16 \mathrm{ppm}$ which were similar to those observed in 6 . In the ${ }^{13} \mathrm{C}$ NMR spectrum of 6, a typical downfield shift of $\mathrm{C}-4$ " $(+11.0 \mathrm{ppm})$ was observed together with the new $O$-methyl signal at $62.1 \mathrm{ppm}$ compared to 3 . Compound 7 showed downfield shifts of C-11 $(+9.4 \mathrm{ppm})$ and $\mathrm{C}-4^{\prime \prime}(+11.1 \mathrm{ppm})$ together with the $O$-methyl signals at 60.1 and $62.2 \mathrm{ppm}$ compared to 
3. The structures of 6 and 7 were therefore determined to be $6,4^{\prime \prime}$-di- $O$-methyl- and $6,11,4^{\prime \prime}$-tri- $O$ methylerythromycins $\mathrm{B}$, respectively.

The molecular formula of 5 was determined as $\mathrm{C}_{38} \mathrm{H}_{69} \mathrm{NO}_{12}$ from elemental analysis, FAB-MS and ${ }^{13} \mathrm{C}$ NMR spectra, indicating the introduction of a methyl group to 3, which was the same as that of 4 . In the ${ }^{1} \mathrm{H}$ NMR spectrum of 5 , the $O$-methyl signal was newly observed at $3.28 \mathrm{ppm}$. In the ${ }^{13} \mathrm{C}$ NMR spectrum, the $O$-methyl signal $(59.9 \mathrm{ppm})$ and $\mathrm{C}-11(79.3 \mathrm{ppm})$ in 5 were similar to the $11-O$-methyl signal $(60.1 \mathrm{ppm})$ and $\mathrm{C}-11(78.7 \mathrm{ppm})$ in 7 , respectively. The structure of 5 was therefore determined to be 11-O-methylerythromycin B.

Selectivity for methylation of EM-B derivative $\mathbf{8}$ is considerably different from that of EM-A derivative 13. Methylation of 13 with $\mathrm{MeI} / \mathrm{KOH}$ in DMSO-1,2-dimethoxyethane afforded the 11-O-methylated compound as the major product, some 6-O-methylated compound, and small amounts of 6,11- and 6,12-di- $O$-methylated compounds ${ }^{2}$. On the other hand, the 6-hydroxyl group in $\mathbf{8}$ is much more reactive than the 11-hydroxyl and the 4 "-hydroxyl groups. Compound 8 is different from 13 only by the lack of the 12-hydroxyl group. The above significant difference for methylation is caused by the neighboring group effect of the 12-hydroxyl group. We are studying the reason for the selectivities by theoretical calculation using molecular mechanics (MM2') and molecular orbital method (MNDO).

\section{Biological Property}

Table 2 shows the in vitro antibacterial activities of 6-O-methylerythromycins $\mathrm{B}(4,6$ and 7$)$ and 11- $O$-methylerythromycin B (5) compared to those of 1, 2 and 3 against a variety of standard strains. 6-O-Methylerythromycin B (4) is equal to or 2-fold more active than 3, and equal to or 2-fold less active than 2. 11-O-Methylerythromycin $B$ (5) is equal to or 2-fold less active than 4. Di- and tri- $O$-methylerythromycins $B(6$ and 7$)$ are much less active than 4 . The in vivo activities of $1,2,3$ and 4 are listed in Table 3. Compound 4 is 2 -fold more effective than 1 and 3 , but less effective than 2 against experimental infections by Staphylococcus aureus Smith 4 . The hydroxyl group at C-12 plays an important role for in vivo antibacterial activity.

Pharmacokinetic properties of 1, 2,3 and 4 were compared after oral administration to rats in Table

Table 2. In vitro antibacterial activities.

\begin{tabular}{|c|c|c|c|c|c|c|c|}
\hline \multirow{2}{*}{ Strain } & \multicolumn{7}{|c|}{$\operatorname{MICs}(\mu \mathrm{g} / \mathrm{ml})$} \\
\hline & 1 & 2 & 3 & 4 & 5 & 6 & 7 \\
\hline Staphylococcus aureus 209P-JC & 0.10 & 0.10 & 0.20 & 0.10 & 0.20 & 1.56 & 1.56 \\
\hline S. aureus $\mathrm{BB}$ & 0.10 & 0.10 & 0.20 & 0.39 & 0.39 & 3.13 & 3.13 \\
\hline S. aureus Smith 4 & 0.20 & 0.10 & 0.20 & 0.20 & 0.39 & 3.13 & 3.13 \\
\hline S. aureus Terajima & 0.10 & 0.10 & 0.20 & 0.20 & 0.78 & 1.56 & 3.13 \\
\hline S. aureus $\mathrm{J}-109$ & $>100$ & $>100$ & $>100$ & $>100$ & $>100$ & $>100$ & $>100$ \\
\hline S. aureus $\mathbf{B} 1$ & $>100$ & $>100$ & $>100$ & $>100$ & $>100$ & $>100$ & $>100$ \\
\hline S. epidermidis IID 866 & 0.20 & 0.10 & 0.20 & 0.10 & 0.20 & 1.56 & 1.56 \\
\hline S. epidermidis sp-al-1 & 0.39 & 0.20 & 0.39 & 0.20 & 0.20 & 1.56 & 3.13 \\
\hline Bacillus subtilis ATCC 6633 & 0.10 & 0.05 & 0.10 & 0.10 & 0.10 & 0.78 & 1.56 \\
\hline Micrococcus luteus ATCC 9341 & 0.025 & 0.012 & 0.05 & 0.025 & 0.025 & 0.10 & 0.10 \\
\hline Escherichia coli NIHJ JC-2 & 100 & 100 & $>100$ & $>100$ & $>100$ & $>100$ & $>100$ \\
\hline E. coli $\mathrm{K}-12$ & 25 & 12.5 & 25 & 25 & 25 & $>100$ & $>100$ \\
\hline Klebsiella pneumoniae IFO 3317 & 100 & 100 & $>100$ & $>100$ & $>100$ & $>100$ & $>100$ \\
\hline
\end{tabular}

Inoculum size: $10^{6} \mathrm{cfu} / \mathrm{ml}$.

Medium: Sensitivity Test Agar (Eiken). 
Table 3. In vivo antibacterial activities of 1, 2, 3 and 4 in mouse protection test.

\begin{tabular}{llccc}
\hline & \multicolumn{1}{c}{$\mathbf{1}$} & \multicolumn{1}{c}{$\mathbf{2}$} & $\mathbf{3}$ & \multicolumn{1}{c}{$\mathbf{4}$} \\
\hline $\mathrm{ED}_{50}$ & 0.666 & & 0.661 & 0.358 \\
(mg/mouse) & $0.652^{27}$ & $0.086^{2)}$ & & \\
\hline
\end{tabular}

Compounds 1, 2, 3 and 4 were administered orally 1 hour after infection of Staphylococcus aureus Smith 4.

4. AUC's of $\mathbf{4}$ and $\mathbf{2}$ are significantly higher than those of $\mathbf{3}$ and $\mathbf{1}$, which could explain the above excellent in vivo activity.
Table 4. Pharmacokinetic properties of $1,2,3$ and 4 by po administration in rats.

\begin{tabular}{|c|c|c|c|c|}
\hline \multirow[b]{2}{*}{ Compound } & \multirow{2}{*}{$\begin{array}{c}\text { Dose } \\
(\mathrm{mg} / \mathrm{kg})\end{array}$} & \multicolumn{2}{|c|}{ Plasma level } & \multirow{2}{*}{$\begin{array}{c}\text { AUC } \\
(\mu \mathrm{g} \cdot h o u r / \\
\text { ml })\end{array}$} \\
\hline & & $\begin{array}{c}\mathrm{Cmax} \\
(\mu \mathrm{g} / \mathrm{ml})\end{array}$ & $\begin{array}{c}\mathrm{T}_{1 / 2} \\
\text { (hours) }\end{array}$ & \\
\hline 1 & 50 & 0.64 & 2.81 & 2.37 \\
\hline 2 & 50 & 2.40 & 2.47 & 11.17 \\
\hline 3 & 50 & 1.20 & 1.78 & 4.03 \\
\hline 4 & 50 & 1.70 & 1.15 & 15.2 \\
\hline
\end{tabular}

\section{Conclusion}

EM-A (1) has been one of the most useful macrolide antibiotics for the past three decades ${ }^{5,6)}$. We have synthesized clarithromycin (2), which is expected to supersede EM-A as a new antibiotic. This compound exhibits excellent antibacterial activity and preferable pharmacokinetic properties, which were brought by $6-O$-methylation ${ }^{2)}$.

6-O-Methylerythromycin B (4) was synthesized from EM-B (3) in $71 \%$ overall yield. Methylation of the 6-hydroxyl group in $\mathbf{8}$ is considerably regioselective, which could not be presumed from methylation of EM-A derivative (13). Methylation of the 6-hydroxyl group does not affect the in vitro antibacterial activity significantly, but improves the in vivo activity due to the preferable pharmacokinetic properties. 6-O-Methylerythromycin B (4) is expected to be a promising antibiotic as well as clarithromycin (2).

\section{Experimental}

MP's are uncorrected. IR and UV spectra were recorded with a Perkin-Elmer 1760 FT-IR spectrometer and a Shimadzu UV 240 spectrophotometer, respectively. Optical rotations were measured on a Jasco DIP-360 digital polarimeter. NMR spectra were recorded with a Jeol JNM-GX 400 spectrometer. Mass spectra were measured on a Jeol JMS-SX102 spectrometer equipped with a Jeol JMA-DA6000 data system using FAB techniques.

\section{$2^{\prime}-O, 3^{\prime}-N$-Bis(benzyloxycarbonyl)- $N$-demethylerythromycin B (8)}

To a vigorously stirred suspension of $\mathrm{NaHCO}_{3}(270 \mathrm{~g})$ in carbobenzoxy chloride $(500 \mathrm{~g})$ was added $3(135 \mathrm{~g})$ in small portions at $40 \sim 50^{\circ} \mathrm{C}$ for 1 hour. The mixture was stirred for 1.5 hours at the same temperature, and $\mathrm{CH}_{2} \mathrm{Cl}_{2}(350 \mathrm{ml})$ was added. The reaction mixture was filtered, and the solid was washed with $\mathrm{CH}_{2} \mathrm{Cl}_{2}(500 \mathrm{ml})$. The filtrate was evaporated under reduced pressure. Crystallization of the residue from ethyl ether - petroleum ether $(100 \mathrm{ml} / 4.5$ liters $)$ afforded $8(161.8 \mathrm{~g}, 88 \%)$ as colorless needles, $\mathrm{mp}$ $212 \sim 213.5^{\circ} \mathrm{C} ;[\alpha]_{\mathbf{D}}^{25}-112.7^{\circ}(c 0.5, \mathrm{EtOH}) ; \mathrm{UV} \lambda_{\max }^{\mathrm{EtOH}} \mathrm{nm}(\varepsilon) 214(503.8), 252$ (298.1), 258 (273.3), 263 (326.7), 267 (sh), 289 (32.9); IR (KBr) cm ${ }^{-1} 3446,1751,1727,683$; FAB-MS m/z 972 (M+H); Anal Calcd for $\mathrm{C}_{52} \mathrm{H}_{77} \mathrm{NO}_{16}: \mathrm{C} 64.24, \mathrm{H} 7.98, \mathrm{~N}$ 1.44. Found: C 63.96, H 8.03, N 1.35.

$2^{\prime}-O, 3^{\prime}-N$-Bis(benzyloxycarbonyl)- $N$-demethyl-6-O-methylerythromycin $\mathrm{B}$ (9) and $\quad 2^{\prime}-O, 3^{\prime}-N$-Bis(benzyloxycarbonyl)- $N$-demethyl-11-O-methylerythromycin B (10)

To a stirred solution of $8(24.3 \mathrm{~g})$ and $\mathrm{MeI}(3.9 \mathrm{ml}, 2.5$ equiv) in DMSO - 1,2-dimethoxyethane $(1: 1$, $500 \mathrm{ml})$ was added $85 \% \mathrm{KOH}$ powder $\left(2.47 \mathrm{~g}, 1.5\right.$ equiv) at $0 \sim 5^{\circ} \mathrm{C}$ in one portion. After the reaction mixture was stirred for 2.5 hours, triethyl amine $(10 \mathrm{ml})$ was added. The above mixture was poured into $5 \% \mathrm{NaHCO}_{3}$ soln, and extracted with EtOAc. The organic layer was washed with satd $\mathrm{NaCl}$ soln, dried over $\mathrm{MgSO}_{4}$ and evaporated under reduced pressure. The crude product was chromatographed on a silica gel column using EtOAc- $n$-hexane $(1: 2)$ to afford $9(21.4 \mathrm{~g}, 87 \%), 10(1.6 \mathrm{~g}, 6 \%)$ and $11(1.0 \mathrm{~g}, 4 \%)$. Crystallization of 9 from $\mathrm{CHCl}_{3}$ - petroleum ether afforded colorless prisms, mp $102 \sim 106^{\circ} \mathrm{C} ;[\alpha]_{\mathrm{D}}^{26.5}-114.0^{\circ}$ 
(c 0.5, EtOH); UV $\lambda_{\max }^{\mathrm{EtOH}} \mathrm{nm}(\varepsilon) 213$ (488.8), 252 (294.7), 258 (373.8), 263 (328.4), 267 (sh), 289 (31.8); IR $(\mathrm{KBr}) \mathrm{cm}^{-1} 3515,1751,1730$, 1704; FAB-MS $m / z 986(\mathrm{M}+\mathrm{H})$; Anal Calcd for $\mathrm{C}_{53} \mathrm{H}_{79} \mathrm{NO}_{16}$ : C 64.55, H 8.07, N 1.42. Found: C 63.93, H 8.13, N 1.33.

Crystallization of 10 from EtOAc- $n$-hexane afforded colorless prisms, mp $129 \sim 133^{\circ} \mathrm{C}$; $[\alpha]_{\mathrm{D}}^{25}-118.3^{\circ}$ (c 0.5, EtOH); UV $\lambda_{\max }^{\mathrm{EtOH}} \mathrm{nm}(\varepsilon) 214$ (510.3), 252 (301.4), 258 (380.3), 263 (331.0), 267 (sh), 289 (31.8); IR $(\mathrm{KBr}) \mathrm{cm}^{-1} 3523,1752,1729$, 1703; FAB-MS $m / z 986(\mathrm{M}+\mathrm{H})$; Anal Calcd for $\mathrm{C}_{53} \mathrm{H}_{79} \mathrm{NO}_{16}$ : C 64.55, H 8.07, N 1.42. Found: C 64.07, H 8.12, N 1.33 .

\section{$2^{\prime}-O, 3^{\prime}-N$-Bis(benzyloxycarbonyl)- $N$-demethyl-6,4'-di- $O$-methylerythromycin B (11)}

To a stirred solution of $8(0.80 \mathrm{~g})$ and MeI $(0.8 \mathrm{ml}, 16$ equiv) in DMF $(6.4 \mathrm{ml})$ was added $60 \% \mathrm{NaH}$ dispersion (64 mg, 2.0 equiv) at $0 \sim 5^{\circ} \mathrm{C}$ in one portion, and the reaction mixture was stirred for 1.5 hours. Purification as described above afforded $12(80 \mathrm{mg}, 10 \%), 11(420 \mathrm{mg}, 51 \%)$, and $9(170 \mathrm{mg}, 21 \%)$. Compound 11 was obtained as a colorless glass, $\mathrm{mp} 94 \sim 98^{\circ} \mathrm{C} ;[\alpha]_{\mathrm{D}}^{27}-108.4^{\circ}(\mathrm{c} 0.5$, EtOH); UV $\lambda_{\max }^{\mathrm{EtOH}} \mathrm{nm}(\varepsilon) 219$ (603.7), 252 (381.5), 258 (438.7), 263 (381.3), $267(\mathrm{sh}), 289(\mathrm{sh}) ; \mathrm{IR}\left(\mathrm{CHCl}_{3}\right) \mathrm{cm}^{-1}$ 3509, 1745, 1723, 1693; FAB-MS m/z 1,000 (M+H); Anal Calcd for $\mathrm{C}_{54} \mathrm{H}_{81} \mathrm{NO}_{16}: \mathrm{C} 64.84, \mathrm{H} 8.16, \mathrm{~N} 1.40$. Found: C 64.17, H 8.10, N 1.30 .

\section{$2^{\prime}-O, 3^{\prime}-N$-Bis(benzyloxycarbonyl)- $N$-demethyl-6,11,4'-tri- $O$-methylerythromycin B (12)}

To a stirred solution of $8(1.0 \mathrm{~g})$ and MeI $(1 \mathrm{ml}, 16$ equiv) in DMF $(8 \mathrm{ml})$ was added $60 \% \mathrm{NaH}$ dispersion (192 mg, 4.9 equiv) at $0 \sim 5^{\circ} \mathrm{C}$, and the reaction mixture was stirred for 0.5 hour. Similar treatment and purification as described above afforded $12(972 \mathrm{mg}, 93 \%)$. Crystallization of 12 from ethyl ether-petroleum ether afforded colorless needles, mp $187 \sim 189^{\circ} \mathrm{C} ;[\alpha]_{D}^{25}-129.6^{\circ}(c 0.5$, EtOH $)$; UV $\lambda_{\max }^{\mathrm{EtOH}} \mathrm{nm}(\varepsilon) 211(527.0), 252$ (303.3), 258 (386.4), 263 (335.3), 267 (sh), 289 (28.4); IR(KBr) cm ${ }^{-1} 1750$, 1726, 1708; FAB-MS $m / z$ 1,014 $(\mathrm{M}+\mathrm{H})$; Anal Calcd for $\mathrm{C}_{55} \mathrm{H}_{83} \mathrm{NO}_{16}: \mathrm{C} 65.13, \mathrm{H}$ 8.25, N 1.38. Found: C $64.87, \mathrm{H} 8.34, \mathrm{~N} 1.32$.

\section{6-O-Methylerythromycin B (4)}

To a solution of $9(21.42 \mathrm{~g})$ in $2.5 \mathrm{M}$ acetate buffer $(\mathrm{pH} 5.0,24 \mathrm{ml})$ and EtOH $(200 \mathrm{ml})$ was added Pd-black $(1 \mathrm{~g})$ and the mixture was stirred under hydrogen atmosphere for 3 hours at room temperature. After the complete removal of the benzyloxycarbonyl groups, $37 \%$ formaldehyde soln $(40 \mathrm{ml})$ was added and hydrogenation was continued for further 3 hours. The catalyst was filtered off, and ice water (1 liter) was added to the filtrate. The resulting mixture was adjusted to $\mathrm{pH} 10 \sim 10.5$ with $2 \mathrm{~N} \mathrm{NaOH}$ soln under stirring to give the crude crystals. The crystals, collected by filtration, were washed with $2 \% \mathrm{NaHCO}_{3}$ soln and water and dried. Crystallization from $\mathrm{CHCl}_{3}$-petroleum ether afforded $4(14.84 \mathrm{~g}, 93 \%)$. Recrystallization from EtOH gave needles for analyses, $\mathrm{mp} 219 \sim 220^{\circ} \mathrm{C} ;[\alpha]_{\mathrm{D}}^{26.5}-104.0^{\circ}(\mathrm{c} 0.5, \mathrm{EtOH})$; UV $\lambda_{\max }^{\mathrm{ErOH}} \mathrm{nm}(\varepsilon) 217$ (381.2), 289 (30.9); IR $(\mathrm{KBr}) \mathrm{cm}^{-1}$ 3468, 1729, 1692; FAB-MS $m / z 732(\mathrm{M}+\mathrm{H})$; Anal Calcd for $\mathrm{C}_{38} \mathrm{H}_{69} \mathrm{NO}_{12}$ : C 62.36, H 9.50, N 1.91. Found: C 62.70, H 9.40, N 1.74. ${ }^{1} \mathrm{H}$ and ${ }^{13} \mathrm{C}$ NMR data are listed in Table 1.

\section{1-O-Methylerythromycin B (5)}

By the method described above, $10(200 \mathrm{mg})$ was hydrogenated and $N$-methylated. The reaction mixture was filtered, and the filtrate was poured into $\mathrm{NaHCO}_{3}$ soln and extracted with EtOAc. The organic layer was washed with satd $\mathrm{NaCl}$ soln, dried over $\mathrm{MgSO}_{4}$ and evaporated to give the crude product. Column chromatography of the crude product on silica gel with $\mathrm{CHCl}_{3}-\mathrm{MeOH}$ - conc $\mathrm{NH}_{4} \mathrm{OH}(20: 1: 0.1)$ afforded $5(91 \mathrm{mg}, 61 \%)$ as crystalline solid, $\mathrm{mp} 178 \sim 182^{\circ} \mathrm{C} ;[\alpha]_{\mathrm{D}}^{27}-103.2^{\circ}(c 0.25$, EtOH $)$; UV $\lambda_{\max }^{\mathrm{EtOH}} \mathrm{nm}$ (c) 213 (726.4), $285(47.7)$; IR $\left(\mathrm{CHCl}_{3}\right) \mathrm{cm}^{-1} 3452$, 1722; FAB-MS $m / \mathrm{z} 732(\mathrm{M}+\mathrm{H})$; Anal Calcd for $\mathrm{C}_{38} \mathrm{H}_{69} \mathrm{NO}_{12}$ : C 62.36, $\mathrm{H} 9.50, \mathrm{~N}$ 1.91. Found: C 62.09, H 9.32, N 1.75. ${ }^{1} \mathrm{H}$ NMR $\left(400 \mathrm{MHz}, \mathrm{CDCl}_{3}\right)$ $\delta 2.28\left(6 \mathrm{H}, \mathrm{s}, 3^{\prime}-\mathrm{N}\left(\mathrm{CH}_{3}\right)_{2}\right), 2.99\left(1 \mathrm{H}, \mathrm{dd}, 4^{\prime \prime}-\mathrm{H}\right), 3.28\left(3 \mathrm{H}, \mathrm{s}, 11-\mathrm{OCH}_{3}\right), 3.31\left(3 \mathrm{H}, \mathrm{s}, 3^{\prime \prime}-\mathrm{OCH}_{3}\right), 3.99(1 \mathrm{H}$, dd, $11-\mathrm{H}) ;{ }^{13} \mathrm{C} \mathrm{NMR}\left(100.4 \mathrm{MHz}, \mathrm{CDCl}_{3}\right) \delta 40.4\left(3^{\prime}-\mathrm{N}\left(\mathrm{CH}_{3}\right)_{2}\right), 49.4\left(3^{\prime \prime}-\mathrm{OCH}_{3}\right), 59.9\left(11-\mathrm{OCH}_{3}\right), 79.3$ (C-11), 74.7 (C-6), $77.9\left(\mathrm{C}-4^{\prime \prime}\right)$.

6,4"-Di- $O$-methylerythromycin B (6)

By the method described above, $11(600 \mathrm{mg})$ was hydrogenated and $N$-methylated. Column 
chromatography of the crude product on silica gel with $\mathrm{CHCl}_{3}-\mathrm{MeOH}(10: 1)$ and crystallization from EtOH afforded $6(327 \mathrm{mg}, 69 \%)$ as needles which contained $1 \mathrm{~mol}$ of EtOH, mp $200 \sim 201^{\circ} \mathrm{C} ;[\alpha]_{\mathrm{D}}^{26.5}-95.8^{\circ}$ (c 0.47, EtOH); UV $\lambda_{\max }^{\mathrm{EtOH}} \mathrm{nm}(\varepsilon) 216(397.0), 289$ (34.2); IR $(\mathrm{KBr}) \mathrm{cm}^{-1} 3466,1728,1693$; FAB-MS $m / z$ $746(\mathrm{M}+\mathrm{H})$; Anal Calcd for $\mathrm{C}_{39} \mathrm{H}_{71} \mathrm{NO}_{12} \cdot \mathrm{C}_{2} \mathrm{H}_{5} \mathrm{OH}: \mathrm{C} 62.17$, H 9.80, N 1.77. Found: C 61.82, H 9.73, $\mathrm{N} 1.74 .{ }^{1} \mathrm{H}$ NMR $\left(400 \mathrm{MHz}, \mathrm{CDCl}_{3}\right) \delta 2.28\left(6 \mathrm{H}, \mathrm{s}, 3^{\prime}-\mathrm{N}\left(\mathrm{CH}_{3}\right)_{2}\right), 2.66\left(1 \mathrm{H}, \mathrm{d}, 4^{\prime \prime}-\mathrm{H}\right), 3.10\left(3 \mathrm{H}, \mathrm{s}, 6-\mathrm{OCH}_{3}\right)$, $3.33\left(3 \mathrm{H}, \mathrm{s}, 3^{\prime \prime}-\mathrm{OCH}_{3}\right), 3.54\left(3 \mathrm{H}, \mathrm{s}, 4^{\prime \prime}-\mathrm{OCH}_{3}\right), 3.73(1 \mathrm{H}$, dd, $11-\mathrm{H}) ;{ }^{13} \mathrm{C} \mathrm{NMR}\left(100.4 \mathrm{MHz}, \mathrm{CDCl}_{3}\right) \delta 40.2$ $\left(\mathrm{N}\left(\mathrm{CH}_{3}\right)_{2}\right), 49.7\left(3^{\prime \prime}-\mathrm{OCH}_{3}\right), 50.9\left(6-\mathrm{OCH}_{3}\right), 62.1\left(4^{\prime \prime}-\mathrm{OCH}_{3}\right), 69.5(\mathrm{C}-11), 78.7(\mathrm{C}-6), 89.0\left(\mathrm{C}-4^{\prime \prime}\right)$.

\section{$6,11,4^{\prime \prime}$-Tri- $O$-methylerythromycin B (7)}

Similarly $12(830 \mathrm{mg})$ was hydrogenated and $N$-methylated. The crude product was chromatographed on silica gel column with $\mathrm{CHCl}_{3}-\mathrm{MeOH}(20: 1)$ and crystallized from EtOH to afford $7(316 \mathrm{mg}, 48 \%)$, as needles which contained $1 \mathrm{~mol}$ of $\mathrm{EtOH}, \mathrm{mp} 228 \sim 230^{\circ} \mathrm{C}$; IR $(\mathrm{KBr}) \mathrm{cm}^{-1} 3455,1726,1715,1696$; $[\alpha]_{\mathrm{D}}^{26.5}$. $-108.4^{\circ}\left(c 0.47\right.$, EtOH); FAB-MS $m / z 760(\mathrm{M}+\mathrm{H})$; UV $\lambda_{\max }^{\mathrm{EtOH}} \mathrm{nm}(\varepsilon) 217$ (433.0), 287 (40.0); Anal Calcd for $\mathrm{C}_{40} \mathrm{H}_{73} \mathrm{NO}_{12} \cdot \mathrm{C}_{2} \mathrm{H}_{5} \mathrm{OH}$ : C 62.58, $\mathrm{H} 9.88, \mathrm{~N}$ 1.74. Found: $\mathrm{C} 62.42, \mathrm{H} 9.65, \mathrm{~N} 1.70 ;{ }^{1} \mathrm{H}$ NMR $(400 \mathrm{MHz}$, $\left.\mathrm{CDCl}_{3}\right) \delta 2.28\left(6 \mathrm{H}, \mathrm{s}, 3^{\prime}-\mathrm{N}\left(\mathrm{CH}_{3}\right)_{2}\right), 2.66\left(1 \mathrm{H}, \mathrm{d}, 4^{\prime \prime}-\mathrm{H}\right), 3.16\left(3 \mathrm{H}, \mathrm{s}, 6-\mathrm{OCH}_{3}\right), 3.33\left(3 \mathrm{H}, \mathrm{s}, 3^{\prime \prime}-\mathrm{OCH}_{3}\right)$, $3.44\left(3 \mathrm{H}, \mathrm{s}, 11-\mathrm{OCH}_{3}\right), 3.54\left(3 \mathrm{H}, \mathrm{s}, 4^{\prime \prime}-\mathrm{OCH}_{3}\right), 3.51(1 \mathrm{H}, \mathrm{dd}, 11-\mathrm{H}) ;{ }^{13} \mathrm{C} \mathrm{NMR}\left(100.4 \mathrm{MHz}, \mathrm{CDCl}_{3}\right) \delta 40.3$ $\left(3^{\prime}-\mathrm{N}\left(\mathrm{CH}_{3}\right)_{2}\right), 49.7\left(3^{\prime \prime}-\mathrm{OCH}_{3}\right), 50.7\left(6-\mathrm{OCH}_{3}\right), 60.1\left(11-\mathrm{OCH}_{3}\right), 62.2\left(4^{\prime \prime}-\mathrm{OCH}_{3}\right), 78.7(\mathrm{C}-11), 79.3(\mathrm{C}-6)$, $89.1\left(\mathrm{C}-4^{\prime \prime}\right)$.

\section{Acknowledgments}

We thank Mr. H. KoNDOH for technical NMR assistance, and Mr. T. ONo for antibiotic susceptibility test.

\section{References}

1) Morimoto, S.; Y. Takahashi, Y. Watanabe \& S. Omura: Chemical modification of erythromycins. I. Synthesis and antibacterial activity of 6-O-methylerythromycins A. J. Antibiotics 37: 187 189, 1984

2) Morimoto, S.; Y. Misawa, T. Adachl, T. Nagate, Y. Watanabe \& S. OMura: Chemical modification of erythromycins. II. Synthesis and antibacterial activity of $O$-alkyl derivatives of erythromycin A. J. Antibiotics 43 : $286 \sim 294,1990$

3) Pettinga, C. W.; W. M. Stark \& F. R. VAN Abeele: The isolation of a second crystalline antibiotic from Streptomyces erythreus. J. Am. Chem. Soc. 76: $569 \sim 571,1954$

4) Flynn, E. H.; H. W. MurPhy \& R. E. MCMahon: Erythromycin. II. Des- $N$-methylerythromycin and $N$-methyl-C ${ }^{14}$-erythromycin. J. Am. Chem. Soc. 77: 3104 3106, 1955

5) Washington, J. A., II \& W. R. Wilson: Erythromycin: A microbial and clinical perspective after 30 years of clinical use (First of two parts). Mayo Clin. Proc. 60: 189 203, 1985

6) Washington, J. A., II \& W. R. Wilson: Erythromycin: A microbial and clinical perspective after 30 years of clinical use (Second of two parts). Mayo Clin. Proc. 60: $271 \sim 278,1985$ 